\title{
Increased monocyte tissue factor expression in coronary disease
}

\author{
E W Leatham, P M W Bath, J A Tooze, A J Camm
}

\begin{abstract}
Objective-To investigate whether monocyte expression of tissue factor is increased in patients with acute coronary syndromes and chronic stable angina. Design-Cross sectional study of monocyte tissue factor expression in patients with ischaemic heart disease and control subjects.
\end{abstract}

Background-Unstable angina and myocardial infarction are associated with enhanced mononuclear cell procoagulant activity. Procoagulant activity of blood monocytes is principally mediated by tissue factor expression. Tissue factor initiates the coagulation cascade, and monocyte tissue factor expression may therefore be increased in these syndromes.

Methods-Monocyte tissue factor expression was measured cytometrically in whole blood flow using a polyclonal rabbit antihuman tissue factor antibody.

Patients-30 patients with acute myocardial infarction, 17 with unstable angina, 13 with chronic stable angina, and 11 normal control subjects.

Results-Increased proportions of monocytes expressing tissue factor $(>2.5 \%)$ were found in none of $11(0 \%)$ normal subjects, five of $13(38 \%)$ patients with stable angina, 11 of 17 (64\%) patients with unstable angina, and 16 of 30 (53\%) patients with myocardial infarction $(2 P=$ 0.006). Blood from all subjects showed similar monocyte tissue factor expression (46.1 (15.1)\%) after lipopolysaccharide stimulation.

Conclusion-Hypercoagulability associated with acute myocardial infarction, unstable angina, and chronic stable angina may be induced by tissue factor expressed on circulating monocytes.

\section{(Br Heart f 1995;73:10-13)}

Keywords: monocytes, tissue factor, coronary heart disease.

Monocytes exhibit marked procoagulant activity in vitro after stimulation with endotoxin, ${ }^{1}$ tumour necrosis factor, ${ }^{2}$ and a wide variety of other immunological and inflammatory stimuli..$^{3-7}$ Similar procoagulant activity has been described in monocytes isolated from animals injected with endotoxin ${ }^{8}$ and in humans presenting with various medical disorders associated with hypercoagulability. ${ }^{4-11}$ Enhanced procoagulant activity has also been described in monocytes from patients with unstable angina, where the degree of procoagulant activity was found to correlate with markers of thrombin production. ${ }^{12}$

Mononuclear cell procoagulant activity is mediated by the expression of tissue factor on the surface of monocytes. ${ }^{1314}$ Tissue factor is a $47 \mathrm{kDa}$ integral membrane glycoprotein made up of 263 amino acids. Tissue factor binds to coagulation factor Vlla, initiating intrinsic and extrinsic pathways of the coagulation cascade. ${ }^{1516}$

A mononuclear procoagulant assay measures the ability of mononuclear cells to clot plasma, and is relatively non-specific. The technique is time consuming because mononuclear cells have to be separated from plasma and erythrocytes. Instead, we have measured tissue factor expression on monocytes in whole blood using polyclonal rabbit antibodies raised against recombinant human tissue factor. Precise measurement of antibody binding to the surface of monocytes was achieved using flow cytometry.

\section{Patients and methods}

PATIENTS

Thirty consecutive patients with acute myocardial infarction (24 $Q$ wave, six non- $Q$ wave), and 17 with unstable angina admitted to the coronary care unit were studied between February and October 1993. In addition, 13 patients with stable, but severe, angina requiring elective revascularisation (coronary artery bypass surgery 10 , percutaneous transluminal coronary angioplasty three) and 11 normal control subjects were studied. Myocardial infarction and unstable angina (spontaneous angina) were defined using standard World Health Organisation criteria. ${ }^{17}$ This definition includes patients with symptoms of coronary ischaemia at rest, but does not include deteriorating angina on exertion. Patients presenting with acute coronary syndromes were only included if coronary chest pain lasting more than 10 minutes had occurred at rest within 24 hours of blood sampling, although the original onset of chest pain may have occurred days before. In addition, only patients with unstable angina associated with transient electrocardiographic changes were selected (ST segment or T wave changes).

Eleven control subjects were selected from consecutive patients attending the outpatient phlebotomy room for "screening" blood tests arranged by general practitioners; these were in good health and receiving no drugs. We 
excluded all patients with clinically obvious intercurrent infection, malignancy, or other serious medical disorders. The study protocol was approved by St George's Hospital medical ethics committee.

\section{SAMPLE COLLECTION}

Demographic and medical details (table) including type of myocardial infarction and interval between onset of chest pain and blood sampling were collected. A single sample of blood was collected from each patient between 8 and $10 \mathrm{am}$. Two millilitres of venous blood was drawn from a 19 gauge butterfly into a prechilled, heparised syringe and kept on melting ice until analysis. Half the blood was stimulated with $10 \mu \mathrm{g} / \mathrm{ml}$ lipopolysaccharide (Sigma, Luton, United Kingdom) for three hours to assess the maximum potential of monocytes to express tissue factor.

\section{MEASUREMENT OF MONOCYTE TISSUE FACTOR EXPRESSION}

A $100 \mu \mathrm{l}$ volume of unstimulated or lipopolysaccharide stimulated blood was incubated with $2 \mu \mathrm{g}$ of rabbit antihuman tissue factor for 30 minutes at $4^{\circ} \mathrm{C}$. This rabbit antihuman antibody was shown previously to have high specificity for human tissue factor in western blot experiments, and blocked the functional activity of tissue factor in procoagulant assays.

Red cells were lysed with Q-prep solutions (Coulter Corporation, Luton, United Kingdom). Cells were washed twice in chilled phosphate buffered saline before incubating with fluoroscein conjugated swine antirabbit antibody for 30 minutes. Cells were rewashed twice and fixed with $1 \%$ paraformaldehyde before flow cytometric analysis.

Non-specific binding of antibodies was assessed for the primary and secondary antibodies, using irrelevant control antibodies (rabbit antichicken and swine antirabbit antibodies respectively). These controls allowed us to find an appropriate threshold of surface fluorescence on unstimulated cells from normal subjects, above which only low levels $(<2.5 \%)$ of non-specific binding occurred.

\section{FLOW CYTOMETRY}

A Becton Dickinson flow cytometer (FacScan), Becton Dickinson, Mountain

Patient demographic details. Median value (interquartile) of frequency (percentage). Comparisons made using Kruskal-Wallis test or $\chi^{2}$ test. $P<0.05$ and $2 P<0.05$ Comparisons made using Kruskal-
respectively considered significant

\begin{tabular}{|c|c|c|c|c|c|}
\hline & $\begin{array}{l}\text { Myocadial } \\
\text { infarction } \\
(n=30)\end{array}$ & $\begin{array}{l}\text { Unstable } \\
\text { angina } \\
(n=17)\end{array}$ & $\begin{array}{l}\text { Chronic } \\
\text { stable angina } \\
(n=13)\end{array}$ & $\begin{array}{l}\text { Normal } \\
\text { controls } \\
(n=11)\end{array}$ & P Value \\
\hline $\begin{array}{l}\text { Age (years) } \\
\text { Male (\%) } \\
\text { White (\%) } \\
\text { Smokers` }(\%) \\
\text { Time between first } \\
\text { onset of symptoms } \\
\text { and study entry } \\
\text { (hours) }\end{array}$ & $\begin{array}{l}60(15) \\
25(83) \\
28(93) \\
11(37)\end{array}$ & $\begin{array}{r}61(20) \\
13(76) \\
14(82) \\
5(29)\end{array}$ & $\begin{array}{rr}67 & (17) \\
12 & (92) \\
13 & (100) \\
1 & (8)\end{array}$ & $\begin{array}{r}51(21) \\
7(64) \\
8(72) \\
2(18)\end{array}$ & $\begin{array}{l}0.22 \\
0.32 \\
0.12 \\
0.22\end{array}$ \\
\hline
\end{tabular}

*Smokers: current or within one month.
View, California, USA) was used to measure monocyte tissue factor expression. Leucocytes were gated on forward and side scatter. Pilot experiments showed the monocyte population to be CD14 (Coulter) positive (92 (5)\%). Leucocyte surface fluorescence was measured using 10000 cells for each sample.

After the determination of tissue factor expression in normal subjects, we set a threshold value of $2.5 \%$ tissue factor positive cells, based on measurement of six normal laboratory staff, who all had tissue factor expression $<2.5 \%$ (median (IQR) $1 \cdot 1(0 \cdot 2)$ ). Patients with $<2.5 \%$ positive cells were considered negative for tissue factor, patients with $>2.5 \%$ positive cells were considered positive. The flow cytometer was calibrated each day with calibration beads (CMPC, Hato Rey, Puerto Rico), which enabled the threshold for the detection of monocyte tissue factor to be standardised for each measurement.

\section{STATISTICAL ANALYSIS}

The patient characteristics are described using the median and interquartile range. Comparisons were made using the KruskalWallis for multiple group data and the $\chi^{2}$ test for frequency data. Probability values of $\mathbf{P}<0.05$ (Kruskal-Wallis) or $2 \mathrm{P}<0.05\left(\chi^{2}\right)$ were considered significant.

\section{Results}

\section{PATIENT CHARACTERISTICS}

The four patient groups were matched, with no difference found for age, race, gender, and interval between the initial onset of chest pain and time of blood sampling (table).

MONOCYTE TISSUE FACTOR EXPRESSION

Increased tissue factor expression was observed in 32 of the 71 patients studied. Figure 1 shows representative histograms of surface tissue factor expression in one patient with myocardial infarction and one normal control. All normal control subjects had a low proportion $(<2.5 \%)$ of tissue factor positive cells (fig 2). In contrast, patients with chronic stable angina, unstable angina, and myocardial infarction showed variable proportions of monocytes expressing tissue factor (fig 2). Specifically, none of $11(0 \%)$ normal subjects, five of $13(38 \%)$ patients with stable angina, 11 of $17(64 \%)$ patients with unstable angina, and 16 of $30(53 \%)$ patients with myocardial infarction had increased proportions of tissue factor positive monocytes. These proportions were significantly different between groups $\left(\chi^{2}=12 \cdot 7, \quad 2 P=0.006, \quad d f=3\right)$. Further analysis showed a trend of increasing tissue factor expression with increasing severity (ordered as normal, angina, unstable angina, myocardial infarction $\left(\chi^{2}=8 \cdot 2,2 \mathrm{P}=0.005\right.$, $\mathrm{df}=1)$ ). In contrast, stimulation of blood with lipopolysaccharide caused an increase in the proportion of monocytes expressing tissue factor to above $2.5 \%$ in all subjects (fig 3). The mean (SD) percentage positivity was $46 \cdot 1(15 \cdot 1) \%$, which was not significant between groups $(P=0 \cdot 86)$. 
Figure 1 Representative histograms of fluorescence intensity (log scale) for (A) a patient with myocardial infarction and (B) a normal control each represents monocytes which are expressing low levels of tissue factor. $A$ second, higher fluorescence peak in the patient with myocardial infarction corresponds with $18 \%$ of monocytes expressing high levels of tissue factor. subject. The major peak in
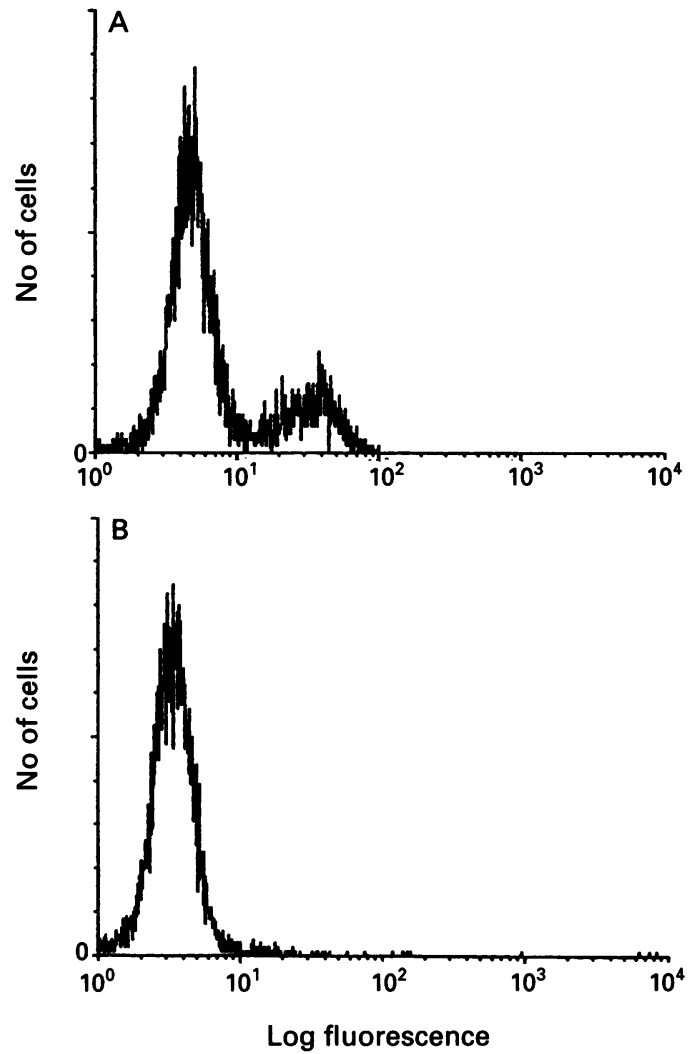

Figure 2 Proportion of tissue factor positive monocytes in unstimulated blood from 11 normal controls (NC), 13 with chronic stable angina (CSA), 17 with unstable angina (UA), and 30 with myocardial infarction (MI). The shaded area (MI). The shaded are
represents the normal proportion of tissue factor positive cells.

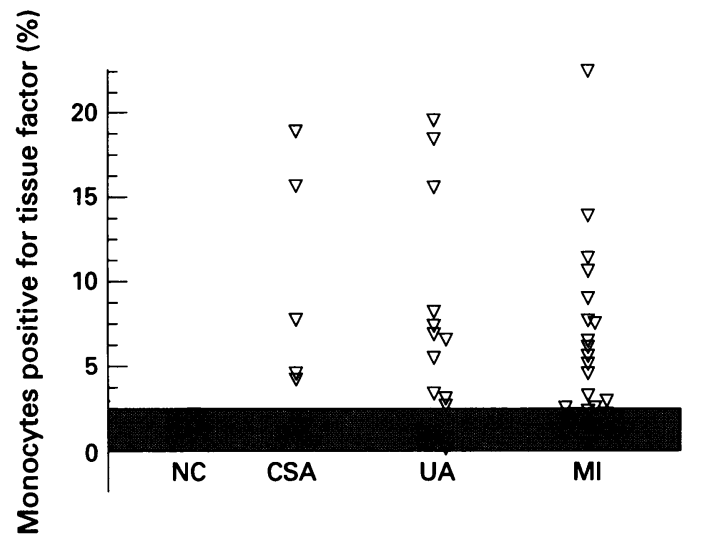

Figure 3 Proportion of tissue factor positive monocytes in stimulated blood in 11 normal control (NC), 11 with chronic stable angina (CSA), 12 with unstable angina (UA), and 19 with (UA), and 19 with
myocardial infarction (MI). The difference observed between groups is not significant (KruskalWallis: $P=0.86$ )

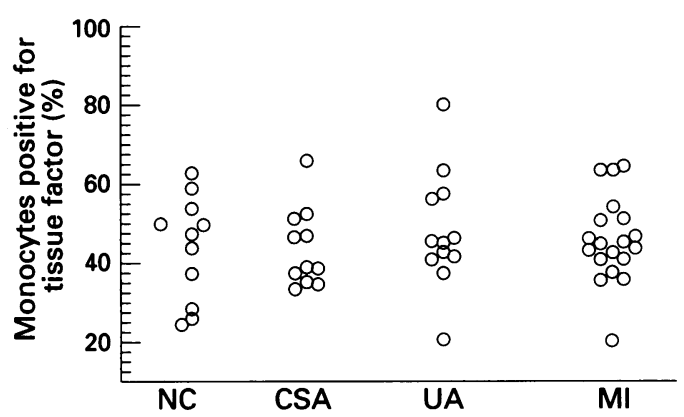

\section{Discussion}

Flow cytometric measurement of tissue factor expressed by Ficoll separated monocytes has previously been shown to correlate well with monocyte procoagulant activity. ${ }^{18}$ The method has been used to show enhanced tissue factor production by monocytes in neonatal infection. ${ }^{9}$ Although a whole blood technique $^{19}$ is now common practice for labelling blood cells with other antibodies, we are the first to describe a whole blood method for assessing monocyte tissue factor expression.
Our method has two advantages over conventional techniques requiring cell separation. Firstly, the time taken to label monocytes is short and the test is therefore more convenient. Secondly, the rapid incubation at $4^{\circ} \mathrm{C}$ reduces the chance of sample contamination with endotoxin, which would cause an artefactual increase in monocyte tissue factor expression.

We have shown for the first time that monocyte tissue factor expression is increased in patients with acute coronary syndromes and chronic stable angina. Neri Serneri et al have shown that separated mononuclear cells show increased procoagulant or "tissue factor like" activity in tissue cultured monocytes of patients with unstable angina compared with convelescent and normal control samples. ${ }^{12}$ One other report of increased monocyte related procoagulant activity in unstable angina has been published in abstract form. ${ }^{20}$ Our studies indicate that such mononuclear cell procoagulant effects are mediated, in part, by tissue factor expressed on monocytes.

Both intrinsic and extrinsic coagulation pathways are activated by tissue factor. Thus tissue factor expression on circulating monocytes will cause a systemic procoagulant state, which may have a role in atherothrombosis. Furthermore, as monocyte adhesion, migration, and transformation into tissue macrophages is known to occur at the site of atherosclerotic plaque, focal production of tissue factor may explain the propensity for thrombosis at the site of atherosclerosis.

The cause of increased tissue factor expression in patients with coronary disease is currently unclear. One possible explanation is that tissue factor expression is reactive or follows tissue necrosis. This is unlikely to explain all of our findings, as tissue factor expression was increased in patients with unstable angina and chronic stable angina, where recent monocyte necrosis had not occurred. Furthermore, tissue factor expression did not correlate with $\mathrm{C}$ reactive protein, an acute phase reactant, when 28 patients were tested (data not shown). Alternatively, or in addition, an increase in monocyte tissue factor expression may precede acute coronary syndromes and predispose to their development. One possible sequence of events is that infection precedes acute coronary ischaemia and thereby leads to an increase in monocyte tissue factor expression. For example, there have been several reports showing an association between Chlamydia pneumoniae infection and coronary disease. ${ }^{21} 22$ Monocyte tissue factor expression can be induced in vitro by a variety of stimuli including bacterial endotoxins, ${ }^{18}$ soluble immune complexes, ${ }^{23}$ lectines, ${ }^{5}$ lymphokines, ${ }^{24}$ viruses, ${ }^{25}$ and chemically modified low density lipoprotein. ${ }^{26}$ Similar stimulation may occur in response to infection in vivo. Thus infection may lead to enhanced monocyte tissue factor expression, which induces a hypercoagulable state.

The hypothesis that a population of hyperfunctional monocytes is produced before myocardial infarction (perhaps secondary to 
infection), with enhanced potential for expressing tissue factor, is a less likely explanation as our patients' monocytes did not express more tissue factor than controls after lipopolysaccharide stimulation. A limitation of the study is that we did not test monocyte tissue factor expression after incubation with a range of various concentrations of lipopolysaccharide; hence it is possible that differences in the responsiveness of monocytes to lipopolysaccharide could have been missed by testing at a single lipopolysaccharide concentration. Increased mononuclear cell procoagulant activity in unstable angina was found by Neri Serneri et al to return to a normal baseline over four weeks. ${ }^{12}$ We have shown increased expression of monocyte tissue factor in a small number of patients with chronic stable angina. Our observation suggests that the phenomenon of enhanced monocyte tissue factor expression may be less transient than expected. The increased concentrations observed in these patients should be regarded with caution, however, as they all had severe coronary artery disease requiring intervention and hence were not representative of most patients with chronic stable angina.

It is interesting to note that not all patients with acute coronary syndromes showed an increase in the percentage of tissue factor positive monocytes. This does not invalidate the hypothesis that monocytes initiate thrombosis as tissue factor expression is only one of several leucocyte mechanisms known to induce thrombosis. Monocytes have been shown to produce several constituents of the clotting cascade, including factors V, VII, VIII, Mac-1 dependent factor $\mathrm{X}$, and prothrombinase. ${ }^{14} 27$

In summary, acute and chronic coronary syndromes are associated with increased tissue factor expression. As tissue factor initiates the clotting cascade, it is possible that an element of coronary thrombosis in coronary artery disease is induced by activated monocytes. This could potentiate thrombosis related to platelet aggregation and adhesion to the endothelium after the rupture of a coronary plaque.

We thank Dr E Tuddenham and Dr D Martin, Thrombosis Research Group, Clinical Research Centre, Northwick Park Hospital, Harrow, Middlesex for supplying the rabbit antihuman tissue factor and rabbit antichicken antibodies. W thank Professor GA MacGregor, BPU and the University of London Central Research Fund for financial support of the project, and Dr $M$ de Belder for his help with the manuscript. Part of this work was presented at the American Hear Association, Atlanta, 1993.28

1 Rivers R, Hathaway $W$, Weston $W$. The endotoxininduced coagulant activity of human monocytes. $\mathrm{Br} f$ Haematol 1975;30:311-6.

2 Conkling $\mathrm{P}$, Greenberg $\mathrm{C}$, Weinberg J. Tumour necrosis factor induces tissue-factor-like activity in human leukaemia cell line U937 and peripheral blood monocytes. Blood 1988;72:128-33.
3 Drake TA, Hannani K, Fei H, Lavi S, Berliner JA. Minimally oxidised low-density lipoprotein induces issue factor expression in cultured human endothelial cells. Am F Pathol 1991;138:601-7.

4 Lyberg T, Prydz N, Baklien K, Hoyeraal HM. Effects of immune complex-containing sera from patients with rheumatic diseases on thromboplastin activity of monocytes. Thromb Res 1982;25:193-202.

5 Prydz H, Lyberg T, Deteix P, Allison AC. In vitro stimulation of tissue thromboplastin (Factor III) activity in human monocytes by immune complexes and lectins. Thromb Res 1979;15:465-74.

6 Petterson KS, Wiiger T, Narahara N, et al. Induction of tissue factor synthesis in human umbilical vein endothelial cells involves protein kinase C. Thromb Haemostas 1992; 67:473-7.

7 Kornberg A, Catane R, Peller S, Kaufman S, Fridkin M. Tuftsin induces tissue factor-like activity in human Tuftsin induces tissue factor-like activity in human
mononuclear cells and in monocytic cell lines. Blood mononuclear cells

8 Niemetz J. Coagulant activity of leucocytes. Tissue factor activity. F Clin Invest 1972;51:307-313.

9 Rivers RP, Cattermole HE, Wright I. The expression of surface tissue factor apoprotein by blood monocytes in the course of infections in early infancy. Pediatr Res 1992;31:567-73.

10 Østerud B, Flaegstad T. Increased tissue thromboplastin activity in monocytes of patients with meningococcal infection: related to an unfavourable prognosis. Thromb Haemostas 1983;49:5-7.

11 Lorenzet R, Peri G, Locati D, et al. Generation of procoagulant activity by mononuclear phagocytes: a possible mechanism contributing to blood clotting activation within malignant tissues. Blood 1983;62:271-3.

12 Neri Serneri G, Abbate $R$, Gori $A$, et al. Transient intermittent lymphocyte activation is responsible for the mittent lymphocyte activation is responsible for the

13 Rickles FR, Levin J, Hardin JA, et al. Tissue factor generation by human mononuclear cells: effects of endotoxin and dissociation of tissue factor generation from mitoand dissociation of tissue factor generation from

14 Edwards RL, Rickles FR. The role of leucocytes in the activation of blood coagulation. Semin Hematol 1992; 29:202-12.

15 Nemerson Y. Tissue factor and hemostasis. Blood 1988;71: 1-8.

16 Rapaport SI, Mohan Rao L. Initiation and regulation of tissue-factor dependent blood coagulation. Arteriosclerosis Thromb 1992;12:1111-21.

17 WHO (Report of the Joint International Society and Federation of Cardiology/World Health Organisation Task Force on Standardization of Clinical Nomenclature). Nomenclature and criteria for diagnosis of ischemic heart disease. Circulation 1979;59:607-9.

18 Luther T, Flossel C, Hietschhold V, Koslowski R, Muller $M$. Flow cytometric analysis of tissue factor (TF) expression on stimulated monocytes-comparison to procoagulant activity of mononuclear blood cells. Blut 1990; agulant activ

19 Caldwell CW, Taylor HM. A rapid, no-wash technique for immunophenotypic analysis by flow-cytometry. $\mathrm{Am} f$ Clin Pathol 1985;86:600-7.

20 Agraou B, Jude B, McFadden E, et al. Increase in monocyte procoagulant activity (PCA) in unstable angina (UA), compared to stable angina and coronary angioplasty. F Am Coll Cardiol 1993;21:326A

21 Saikku P, Leinonen V, Tenkanen L, et al. Chronic Chlamydia pneumoniae infection as a risk factor for coronary heart disease in the Helsinki Heart Study. Ann Intern Med 1992;116:273-8.

22 Thom D, Grayston Y, Siscovick DS, et al. Association of prior infection with Chlamydia pneumoniae and angiographically demonstrated coronary artery disease. $7 \mathrm{Am}$ Med Assoc 1992;268:68-72.

23 Rothberger H, Zimmerman TS, Spiegelberg HL, Vaughan $\mathrm{JH}$. Leukocyte procoagulant activity: enhancement of production in vitro by IgG and antigen-antibody comprodes. $\mathcal{f}$ Clin Invest 1977;59:549-57.

24 Geczy CL, Hopper KE. A mechanism of migration inhibition in delayed-type hypersensitivity reactions II. tion in delayed-type hypersensitivity reactions II. Lymphokines promote procoagulant activity

25 Levy GA, Leibowitz J, Edgington TS. Induction of monocyte procoagulant activity by murine hepatatis monocyte procoagulant activity by murine hepatatis
virus type 3 parallels disease susceptibility in mice. $\mathcal{F}$ Exp Med 1981;154:1150-63

26 Schuff-Werner P, Claus G, Armstrong VW, Kostering H, Seidel D. Enhanced procoagulatory activity (PCA) of monocyte/macrophages after in vitro stimulation with chemically modified LDL. Atherosclerosis 1989;78: 109-12.

27 Shands JW. Macrophage procoagulants. Haemostasis 1984; 14:373-7.

28 Leatham EW, Bath PM, Tooze JA, Tuddenham E, Kaski $\mathrm{J}$-C. Monocytes express increased tissue factor in unstable angina and myocardial infarction. Circulation 1993;88: I128. 